\title{
Reference values for chinchilla (Chinchilla laniger) blood cells and serum biochemical parameters
}

\author{
Valores de referência para os parâmetros das células e bioquímica \\ sangüínea da chinchila (Chinchilla laniger)
}

\author{
Tális de Oliveira Silva ${ }^{1}$ Luiz Carlos Kreutz ${ }^{2}$ Leonardo José Gil Barcellos ${ }^{3}$ \\ João Borella $^{4}$ Auren Benck Soso ${ }^{4}$ Cleverson Souza $^{5}$
}

\section{ABSTRACT}

Raising chinchilla (Chinchilla laniger) for commercial purpose has increased significantly; however, hematological and serum biochemical reference values have not yet been determined for chinchillas raised in south Brazil. Establishing blood cells and serum biochemistry reference values might be helpful to evaluate health status of chinchillas and might be used as a tool by clinicians. The purpose of this study was to determine the reference values for blood cells and serum biochemistry of Chinchilla laniger. Blood samples were collected by cardiac puncture from 16 adult males, at the time they were killed to remove the fur coat, and from 8 adult males anesthetized with ketamine and xylazine. Blood cell counts and serum biochemistry analysis were performed using standard techniques and the results were expressed as mean \pm SEM. Analysis of blood parameters from post-mortem cardiac punctured and from anesthetized chinchillas indicated that blood samples from anesthetized chinchillas had higher PCV, Hemoglobin, MCHC and WBC $(P<.05)$; in contrast, had lower levels of monocytes, basophils and eosinophils ( $P$ $<.05)$. Serum biochemical parameters were less affected by sampling method: anesthetized chinchillas had lower levels of urea, glucose and triglycerids $(P<.05)$. The data obtained might be useful as a parameter to monitor the health status of chinchillas raised in south Brazil.

Key words: Chinchilla laniger, blood cells, plasma biochemistry, reference intervals.

\section{RESUMO}

\begin{abstract}
A criação de chinchila (Chinchilla laniger) com objetivos comerciais tem crescido muito nos últimos anos. No entanto, os valores de referência para os parâmetros hematológicos e bioquímicos não foram ainda determinados para chinchilas criados no sul do Brasil. O estabelecimento dos valores de referência para esses parâmetros pode servir de auxílio para a avaliação da saúde das chinchilas e servir de auxílio diagnóstico para o clínico. Esse estudo teve como objetivo determinar os valores de referência das células e da bioquímica sangüínea da Chinchilla laniger. As amostras de sangue foram coletadas por meio de punção cardíaca de 16 machos adultos no momento em que os animais foram mortos para remoção da pele, e de 8 machos adultos após anestesia com xylazina e ketamina. A contagem das células sangüíneas e a análise dos parâmetros bioquímicos foram feitas utilizandose métodos padronizados em patologia clínica, e os resultados foram expressos utilizando-se a média \pm SEM. Analisando-se os parâmetros sangüíneos, observou-se que as amostras coletadas de animais descervicalizados apresentaram valores de PCV, hemoglobina, MCHC e WBC elevados $(P<.05) \mathrm{em}$ relação às amostras dos animais anestesiados. No entanto, os parâmetros da bioquímica sangüínea foram menos afetados pelo método de coleta: amostras coletadas de animais anestesiados apresentaram níveis de uréia, glicose $e$ triglicerídeos menores $(P<.05)$ do que amostras dos animais descervicalizados. Os dados obtidos serão úteis como parâmetros para monitorar o estado de saúde das chinchilas.
\end{abstract}

${ }^{1}$ Undergraduate student, Biological Sciences.

${ }^{2}$ Veterinarian, MSc, PhD, Professor, Faculty of Agronomy and Veterinary Medicine (FAMV), Universidade de Passo Fundo (UPF), Campus I, Bairro São José, 99001-970, Passo Fundo, RS, Brazil. Fellowship from the Conselho Nacional de Desenvolvimento Científico e Tecnológico (CNPq -300259/2003-4) Corresponding author:E-mail: lckreutz@upf.tche.br.

${ }^{3}$ Veterinarian, MSc, Doctor, Professor, FAMV, UPF, Brazil.

${ }^{4}$ Undergraduate student, Veterinary Medicine, FAMV, UPF, Brazil.

${ }^{5}$ Veterinarian, MSc., Graduate Student, University of Minnesota, MN, USA. 
Palavras-chave: Chinchilla laniger, células sangüíneas , bioquímica sangüínea, valores de referência.

\section{INTRODUCTION}

Chinchillas (Chinchilla laniger) are small rodents that originated in the Andes region of South America. Because of the unique and valuable fur coat, chinchillas have been bred in captivity with the main objective to produce fur for commercial purposes. In addition, chinchillas have also been widely used as an animal model to study pediatric respiratory and ear infections (FULGHUM, 1982; AUL et al., 1998).

Even thought few infectious diseases affect chinchillas, respiratory and intestinal infections and skin diseases might occur mainly in chinchillas raised in intensive production systems. Health assessment of live chinchillas is difficult because of scarcity of reference intervals for hematological and serum biochemistry parameters. A few reports on chinchilla blood parameters have been published and were based on an unknown number of animals, raised under different conditions used currently, with undefined age, sex and raising conditions (JAKUBOW et al., 1984; JAKUBOW \& GROMADZKA-OSTROWKSA, 1987; JAIN, 1993; ANDERSON, 1998). Thus, establishing reference intervals for several blood parameters might be a useful tool to evaluate health status and to monitor the response of chinchillas to infectious diseases and stressful raising conditions.

The aim of this study was to obtain the reference values for chinchilla raised in south Brazil, using methods routinely used in a clinical pathology laboratory. Even thought the blood was collected by cardiac puncture, a less aggressive method should be used to collect smaller amounts of blood to prevent loss of valuable animal (TAPPA et al., 1989; PAOLINI et al., 1993; CROSSLEY, 1998).

\section{MATERIAL AND METHODS}

Animals and blood sampling

Chinchillas used in this study were raised for commercial purpose. The chinchillas were fed alfalfa (Medicago sativa) and a balanced commercial diet (20\% total protein; $12 \%$ total fiber content; $1.5 \%$ calcium; $0.6 \%$ phosphorus and supplemented with vitamins and minerals) and kept under controlled temperature $\left(22^{\circ} \mathrm{C}\right.$ maximum). Blood samples from 16 adult males ( 8 to 12 months old) were collected by cardiac puncture at the time chinchilla were killed (postmortem group) to remove the fur coat. One third of the blood collected from each animal was transferred to a tube and allowed to clot at room temperature and the remaining was further divided into two other tubes, one containing EDTA and one containing fluoret. Blood samples were also collected in the same manner from 8 adult males anesthetized with ketamine and acepromazine (MORGAN, 1981). Following blood sampling, the anesthetized chinchillas were also killed by cervical rupture, in that all chinchillas had the fur removed for commercial purposes. For blood biochemistry, samples were allowed to clot at room temperature for 2 hours; samples collected with anticoagulant were stored refrigerated for the same period of time. Samples were then centrifuged for 10 minutes at $1500 \mathrm{x}$ g to separate the serum or plasma, respectively. Parameters determined on plasma samples were obtained in the same day in which blood was collected. Serum samples were frozen at $-20^{\circ} \mathrm{C}$ for no more than a week.

Hematological and biochemical analysis

Packed cell volume (PCV) was determined by the microhematocrit method (GOLDENFARB et al., 1971); simultaneously, blood smears and cell counting in Neubauer chambers (using formalin at 1\%) were performed for all samples. The hematimetric indexes (MCV - mean corpuscular volume; $\mathrm{MCH}$ - mean corpuscular hemoglobin; and MCHC - mean corpuscular hemoglobin concentration) were calculated using standard methods.

The following biochemistry parameters were determined by colorimetric methods: albumin (bromocresol green method), inorganic phosphorus (ammonium molibdate method), total protein (biuret method), cholesterol (cholesterol esterase/ oxidase method), total bilirrubine (red azobilirrubine method), magnesium (magnon-sulphonade method), calcium (purple ftalein method), tryglicerids (enzymatic Trinder method). The enzymatic activity of aspartate aminotransferase (AST) and alanine aminotransferase (ALT) were determined by the NADH oxidation method, using a commercial kit. The enzymatic activity of alkaline phosphatase (ALP), was determined using the p-nithophenilphosphate method.

Plasma samples containing fluoret were used to measure glucose (glucose oxidase method), and ureia nitrogen (urease method); hemoglobin was measured on whole blood containing EDTA using the cianometahemoglobin method. All blood biochemistry parameters were performed using standard commercial kits (Labtest Diagnóstica, 
Lagoa Santa, MG) ${ }^{\text {a }}$ in a semi-automated spectrophotometer (Photometer 5010, Boheringer Mannheim).

Statistical analyses were performed using a commercial software package (SSPS 10.0). The reference value was calculated from the arithmetic mean SEM to obtain the $2.5 \%$ and $97.5 \%$ limits. Comparison between samples obtained from killed or anesthetized animals was performed using unpaired 2-tailed $t$-test. Differences were considered significant at $P<.05$.

\section{RESULTS}

Blood samples from twenty-four adult male chinchillas were collected to determine blood cells and biochemical parameters. Sixteen samples were collected at the time chinchilla were killed by cervical rupture (post-mortem group) and 8 samples were collected from anesthetized chinchilla (anesthetized group). Blood cell parameters were affected by sampling method. Analysis of blood parameters from post-mortem cardiac punctured and from anesthetized chinchillas indicated that blood samples from anesthetized chinchillas had higher PCV, Hemoglobin, MCHC and WBC $(\mathrm{P}<.05)$; in contrast, they had lower numbers of monocytes, basophils and eosinophils ( $<$ <.05; Table 1$)$. Serum biochemical parameters were less affected by sampling method: anesthetized chinchillas had lower levels of urea, glucose and triglycerids $(\mathrm{P}<$ .05; Table 2). AST and ALT were not measured in the serum from anesthetized chinchillas due to insufficient sample.

\section{DISCUSSION}

In this study, the hematological and blood biochemistry parameters were determined for captive chinchillas raised in South Brazil. All samples were collected from males that were 8 to 12 months of age, by cardiac puncture, immediately following cervical rupture, or under anesthesia. Captive chinchillas might become very stressed when improperly handled by untrained personnel and might even lose hair prior to killing, making the fur coat unsuitable for further processing. Thus, it would be expected that the collection method employed in this study (cervical rupture vs. anesthesia) could influence the concentration of some of the parameters reported herein. In particular, restraining the animals to inject the anesthetic agent could induce a stress response and alter some parameter. Indeed, anesthetized chinchillas had altered PCV and parameters calculated using PCV values $(\mathrm{P}<.05)$ in comparison to postmortem cardiac punctured animals. As occurs in other animal species (NORDOY \& THORENSEN, 2002), stressful situations might cause epinephrine release, causing release of RBC from the spleen. The same epinephrine release may also have caused an increase in WBC number.

The lower glucose level obtained from anesthetized animals might be explained by sampling time. Blood samples from the anesthetized group were collected a few hours later than the samples collected from postmortem cardiac punctured group. Thus, because chinchillas have nocturnal feeding habits, it is possible that samples collected in the early morning (post-mortem

Table 1 - Blood parameters for adult male Chinchillas (Chinchilla laniger). Samples from group 1 chinchillas were collected by cardiac puncture immediately following cervical rupture (post-mortem group). Group 2 animal were anesthetized before cardiac puncture (anesthetized group). Different letters indicate significant differences between groups $(\mathrm{P}<0.05)$.

\begin{tabular}{|c|c|c|c|c|c|c|}
\hline \multirow[b]{2}{*}{ Parameter } & \multicolumn{3}{|c|}{ Group 1} & \multicolumn{3}{|c|}{ Group 2} \\
\hline & $\mathrm{n}$ & Mean $\left( \pm \mathrm{SEM}^{*}\right)$ & 95\% Confidence Intervalo & $\mathrm{n}$ & Mean $( \pm$ SEM) & $\begin{array}{l}\text { 95\% Confidence } \\
\text { Interval }\end{array}$ \\
\hline Packed cell volume - PCV (\%) & 16 & $37,0(1,2)^{\mathrm{a}}$ & $34,5-39,51$ & 8 & $42,6(1,2)^{b}$ & $39,2-45,9$ \\
\hline Hemoglobin $(\mathrm{g} / \mathrm{dL})$ & 16 & $13,1(0,6)^{\mathrm{a}}$ & $11,6-14,5$ & 8 & $15,6(0,8)^{b}$ & $13,6-17,6$ \\
\hline Red blood cell - RBC (x 10\% $/ \mu \mathrm{L})$ & 16 & $3,8(0,2)^{a}$ & $3,4-4,2$ & 8 & $4,3(0,1)^{a}$ & $4,1-4,6$ \\
\hline Mean corpuscular volume - MCV (fL) & 16 & $101,3(6,8)^{\mathrm{a}}$ & $86,5-116,1$ & 8 & $101,3(3,9)^{\mathrm{a}}$ & $90,4-112,3$ \\
\hline Mean corpuscular Hemoglobin - MCH (pg) & 16 & $3,6(0,3)^{a}$ & $2,8-4,4$ & 8 & $3,6(0,3)^{a}$ & $3,0-4,3$ \\
\hline $\begin{array}{l}\text { mean corpuscular hemoglobin } \\
\text { concentration - MCHC (g/dL) }\end{array}$ & 16 & $35,3(1,2)^{\mathrm{a}}$ & $32,5-38,2$ & 8 & $40,4(1,3)^{b}$ & $36,7-44,1$ \\
\hline White blood cells - WBC ( $\left.\times 10^{3} / \mu \mathrm{L}\right)$ & 16 & $5,2(0,4)^{a}$ & $4,4-6,1$ & 8 & $11,1(1,3)^{b}$ & $8,0-14,3$ \\
\hline Linphocytes (\%) & 16 & $35,0(2,5)^{a}$ & $29,6-40,5$ & 8 & $40,2(3,9)^{\mathrm{a}}$ & $30,9-49,6$ \\
\hline Monocytes (\%) & 16 & $11,5(1,7)^{\mathrm{a}}$ & $7,8-15,2$ & 8 & $6,3(1,2)^{b}$ & $3,6-9,1$ \\
\hline Segmented neutrophils (\%) & 16 & $40,0(3,4)^{a}$ & $32,7-47,2$ & 8 & $46,9(3,9)^{\mathrm{a}}$ & $37,6-56,2$ \\
\hline Bastonated neutrophils (\%) & 16 & $3,0(0,5)^{\mathrm{a}}$ & $1,8-4,2$ & 8 & $2,1(0,7)^{\mathrm{a}}$ & $0,4-3,8$ \\
\hline Basophils (\%) & 16 & $5,3(1,0)^{a}$ & $3,2-7,4$ & 8 & $1,7(0,7)^{\mathrm{b}}$ & $0,9-3,4$ \\
\hline Eosinophil (\%) & 16 & $5,8(0,8)^{\mathrm{a}}$ & $3,9-7,6$ & 8 & $2,6(1,1)^{b}$ & $0,2-5,2$ \\
\hline
\end{tabular}

* Standard error of the Mean 
Table 2 - Serum biochemistry parameter for adult male Chinchillas (Chinchilla laniger). Different letters indicate significant differences between groups $(\mathrm{P}<0.05)$.

\begin{tabular}{|c|c|c|c|c|c|c|}
\hline \multirow[b]{2}{*}{ Parameter } & \multicolumn{3}{|c|}{ Group 1} & \multicolumn{3}{|c|}{ Group 2} \\
\hline & $\mathrm{n}$ & $\begin{array}{c}\text { Mean } \\
\left( \pm \mathrm{SEM}^{*}\right)\end{array}$ & 95\% Confidence Intervalo & $\mathrm{n}$ & Mean ( \pm SEM) & 95\% Confidence Intervalo \\
\hline Albumin (g/dL) & 16 & $4,5(0,4)^{\mathrm{a}}$ & $3,7-5,4$ & 8 & $4,4(0,8)^{\mathrm{a}}$ & $2,4-6,1$ \\
\hline Total protein (g/dL) & 16 & $5,6(0,2)^{a}$ & $5,3-6,0$ & 8 & $5,9(0,2)^{\mathrm{a}}$ & $4,9-6,9$ \\
\hline Creatine kinase (mg/dL) & 16 & $0,8(0,1)^{\mathrm{a}}$ & $0,6-1,0$ & 8 & $0,7(0,03)^{\mathrm{a}}$ & $0,6-0,8$ \\
\hline Urea nitrogen (mg/dL) & 16 & $57,3(5,4)^{\mathrm{a}}$ & $45,7-68,9$ & 8 & $35,4(2,8)^{b}$ & $28,6-42,1$ \\
\hline Glucose (mg/dL) & 16 & $180,0(7,7)^{\mathrm{a}}$ & $163,0-196,9$ & 8 & $136,4(11,9)^{\mathrm{b}}$ & $108,4-164,8$ \\
\hline Cholesterol (mg/dL) & 16 & $\underset{\mathrm{a}}{106,2}(12,6)$ & $77,9-134,4$ & 8 & $94,3(11,2)^{a}$ & $66,8-121,8$ \\
\hline Bilirrubin (mg/dL) & 16 & $0,2(0,04)^{\mathrm{a}}$ & $0,1-0,3$ & 8 & $0,3(0,1)^{\mathrm{a}}$ & $0,1-0,6$ \\
\hline Triglycerids (mg/dL) & 16 & $\underset{\mathrm{a}}{173,3}(24,8)$ & $117,0-229,5$ & 8 & $72,7(9,1)^{b}$ & $49,1-96,2$ \\
\hline Alkaline phosphatase (UI/L) & 16 & $44,2(3,0)^{\mathrm{a}}$ & $37,3-51,1$ & 8 & $53,6(9,7)^{\mathrm{a}}$ & $26,5-80,6$ \\
\hline Calcium (mg/dL) & 16 & $9,5(0,9)^{\mathrm{a}}$ & $7,4-11,5$ & 8 & $8,1(1,1)^{\mathrm{a}}$ & $5,4-10,7$ \\
\hline Magnesium (mg/dL) & 16 & $3,8(0,2)^{a}$ & $3,3-4,2$ & 8 & $4,2(0,4)^{a}$ & $3,3-5,0$ \\
\hline AST/TGO & 12 & $249,4(21,8)$ & $201,9-297,0$ & & $\mathrm{Nd}$ & $\mathrm{Nd}$ \\
\hline ALT/TGP & 12 & $39,9(4,2)$ & $30,7-49,1$ & & $\mathrm{Nd}$ & $\mathrm{Nd}$ \\
\hline
\end{tabular}

* Standard error of the mean.

nd: not done

group) could have higher glucose levels, as the result of post prandial hyperglycemia, than samples collected at midday (anesthetized group). Recent feeding might also have contributed to the higher urea and triglycerids levels observed in the post-mortem cardiac punctured group of chinchilla, in that urea is and indication of protein catabolism. The same explanation might also apply to the higher levels of triglycerids obtained in samples collected from more recently fed animals (post-mortem group). It is interesting to note that for these parameters (glucose, urea and triglycerids), the reference interval for anesthetized animals (108.4 - $164.8 \mathrm{mg} / \mathrm{dL}$ for glucose, 28.6 - $42.1 \mathrm{mg} / \mathrm{dL}$ for urea and 49.1 - $96.2 \mathrm{mg} / \mathrm{dL}$ for triglycerids) fell just below the reference values observed for the post-morten cardiac puncutred chinchillas.

Data reported herein regarding hematological and serum biochemical parameters for chinchilla differ from data reported previously (JAKUBOW et al., 1984; JAIN, 1993; ANDERSON, 1998). However, it must be pointed out that no information was given regarding the sex, age, feeding and number of animals sampled to obtain those values. The data reported in the present work was obtained analyzing blood and serum from healthy adult males (8 to 12 months of age), raised in captivity for commercial purposes.

No research has been published relating changes in blood parameter values during acute or chronic diseases in chinchillas. Even thought cardiac puncture has been used to obtain blood samples, an alternative blood sampling method should be used to obtain enough blood for routine analysis (TAPPA et al., 1989; CROSSLEY, 1998; PAOLINI et al., 1993), mainly in animal that will be kept alive after blood sampling, in that this method might cause lesions in cardiac muscle, cardiac blood vessels and even death of valuable animals. Nonetheless, values reported in the present work might be a useful starting point to evaluate the health status in chinchillas and for establishing a relationship between blood parameters and diseases.

\section{ACKNOWLEDGEMENTS}

The authors are grateful to Naiara Schwantes for technical assistance and to Laura Beatriz Rodrigues and Stella de Faria Valle for helpful discussion.

\section{ACQUISITIONSOURCE}

a Labtest Diagnóstica, Lagoa Santa, MG, Brazil

\section{REFERENCES}

ANDERSON, N.L. Criação e medicina básica dos animais de estimação “de bolso”. In: BIRCHARD, S.J.; SHERDING, R.G. Clínica de pequenos animais. São Paulo, SP : Roca, 1998. Cap.10, p.1523-1552.

AUL, J.J. et al. Comparative evaluation of culture and PCR for the detection and determination of persistence bacterial strains and DNAs in the Chinchilla laniger model of otitis media. Ann Otol Rhinol Laryngol, n.107, p.508-513, 1998. 
CROSSLEY, D. Blood testing chinchillas [letter]. Vet Rec, v.142, n.12, p.316, 1998.

FULGHUM, R.S. et al. Experimental otitis media in gerbils and chinchillas with Streptococcus pneumoniae, Haemophilus influenzae, and other aerobic and anaerobic bacteria. Infect Immunity, n.36, p.802$810,1982$.

GOLDENFARB, P.B. et al. Reproducibility in the hematology laboratory: the microhematocrit determination. Am J Clin Pathol, v.56, n.1, p.35-39, 1971.

JAIN, N.C. Comparative hematologic features of some avian and mammalian species. In: (Ed). Essentials of veterinary hematology. Philadelphia : Lea \& Febiger, 1993. Chap.3, p.55-71.

JAKUBOW, K. et al. Seasonal changes in the hematological indices in peripheral blood of chinchilla (Chinchilla laniger L.). Comp Biochem Physiol A, v.78, n.4, p.845-853, 1984.

JAKUBOW, K.; GROMADZKA-OSTROWKSA, J. Twenty- four hour changes in lysozyme levels, total plasma protein concentration, gamma-globulin concentration, white blood cell count and numbers of lymphocytes and granulocytes in the peripheral blood of chinchillas Chinchilla laniger M. and rabbits Oryctolagus cuniculus L. Comp Biochem Physiol A, v.86, n.1, p.109-112, 1987.

MORGAN, R.J. et al. Ketamine-acepromazine as an anesthetic agent for chinchillas (Chinchilla laniger). Lab Anim, n.15, p.281-283, 1981.

NORDOY, E.S.; THORENSEN, S.I. Reference values for serum biochemical parameters in free-ranging harp seals. Vet Clin Pathol, v.31, n.3, p.98-105, 2002.

PAOLINI, R.V. et al. A reliable method for large volume blood collection in the chinchilla. Lab Animal Sci, v.43, n.5, p.524-525, 1993.

TAPPA, B. et al. A simple method for intravenous injection and blood collection in the chinchilla (Chinchilla laniger). Lab Anim, n.23, p.73-75,1989. 